\title{
“FICTIONAL BIOGRAPHIES OF JOSEF KNECHT THROUGH THE PRIZM OF TRANSPERSONAL PSYCHOLOGY (BASED ON HERMAN HESSE'S NOVEL"THE GLASS BEAD GAME")
}

\author{
Ivan Megela \\ Doctor of Sciences in Philology, Professor at the Department of Foreign Literatures, \\ Taras Shevchenko National University of Kyiv, \\ Member of the Academy of Sciences of Higher Education of Ukraine, Ukraine \\ e-mail: imegela@ukr.net,orcid.org/0000-0002-1315-6472
}

\section{Kateryna Mehela}

Candidate of Sciences in Philology, Assistant at the Department of Foreign Languages for Natural Sciences Faculties, Taras Shevchenko National University of Kyiv, Ukraine e-mail: ekaterinamehela@gmail.com,orcid.org/0000-0002-5362-3194

\section{Summary}

The article focuses on three biographies of Josef Knecht from the novel by Hermann Hesse "The Glass Bead Game" with regard to the postulates of transpersonal psychology. A thorough study provides insight into the peculiarities of a unique literary technique - the transfer of the "self" into different historical periods by means of imagination, as a kind of "way to self", devotion to truth through pagan voluntary sacrifice ("Rainmaker"), the ascetic self-denial of a Christian schemamonk ("The Father Confessor"), the life of an Indian ascetic ("Siddhartha"), understanding that all being is illusionary. The research highlights the similarity of plot events, names, integration of esoteric and exoteric perspectives. The study reviews a holotropic state of consciousness, which can develop into psychoid experience, accounting for the impossible to become possible. Based on the judgments of the direct relationship between the concepts of the macrocosm and the microcosm, the perception of reality as a result of human intellectual activity, it is specified that the efforts of the "possible human", "virtual human" to liberate themselves from the dualistic perception of reality is accomplishable by acquiring the unity of consciousness. The authors point out that the review of the motive of "awakening" indicates Hesse's intention to embody absolute transcendent reality in his characters, which could manage the crisis of splitting consciousness.

Keywords: esotericism, macrocosm, microcosm, "possible human", "virtual human", dualistic perception of reality, unity of consciousness, "awakening" motive, holotropic state of consciousness, splitting of consciousness.

DOI: https://doi.org/10.23856/4707

\section{Introduction}

The majority of Hesse's prose works, in the writer's view, are "biographies of the soul", written in different periods of a socio-political and personal mental crisis, against the background of remarkable changes in the natural sciences and the psychology of consciousness; therefore, more innovative approaches and advanced methodology are required to provide insight into literary messages of the writer. 


\section{Literature review}

In the 1950s and 1960s, the rapid growth of interest in Eastern philosophies and the contemporary findings on the human psyche (sensory deprivation, biological feedback) generated the claims that human consciousness is something more than an accidental by-product of neurophysiological and biochemical processes. Stanislav Grof argues that human consciousness and psyche can be considered an expression and reflection of cosmic intelligence permeating the entire universe. Humans are not just highly evolved animals with biological computers built into their skulls, they are also infinite fields of consciousness that surpass time, space, matter, and linear causality (Grof, 2016).

Therefore, the scope of transpersonal psychology is determined primarily by altered states of consciousness, which urge an individual to change their values, result in spiritual rebirth, and assume integrity (Grof \& Grof, 1986). The theoretical background of transpersonal psychology, as evidenced by numerous research, is the studies of medieval mystics, in particular Johann Eckhart, Eastern philosophies: Sufism, Buddhism, Advaita Vedanta, Yoga, as well as the shamanistic traditions of ancient civilizations with a set of ideas about the energy basis of the world and, definitely, the analytical psychology of C.G. Jung. (Jung, 2009).

Ideologically, the innovating approach in psychology is based on contemporary studies on the human brain and discoveries in the field of quantum mechanics, in particular the research conducted by a neurosurgeon Carl Pribram (Pribram, 2013) and physicist David Bohm (Bohm, 2005). Hume L., \& Drury N., point out that these studies contribute to firm judgments that "the fiction believed to be individual consciousness, actually, includes the full potential of universal consciousness, meanwhile the reality we are so sure of is perhaps just one small fraction of a much broader spectrum that we cannot fit into with the limitations of our perception" (Hume \& Drury, 2013).

The current research considers human consciousness with this particular regard (Wilber, 1975) as a hierarchical sequence of stages from the lowest levels to the highest: the prepersonal, pre-egoistic, personal, supra-personal (trans egoistic) (Wilber, 2001).

Hermann Hesse's works in general and notably the novel "The Glass Bead Game" are of constant concern to scholars, critics, and the aspects related to the topicality, genre structure, and narrative system are of particular interest. Along with the traditional adherence to the analytical psychology of C. G. Jung, the range of research tools is enriched with innovative interdisciplinary methods and approaches that significantly expand the view on the writer's idiosyncratic world perception and mindset, allowing to consider Hesse as a forerunner of a number of new concepts, particularly of planetary culture (Seredkin, 1999).

The writer's aesthetic and philosophical viewpoint can primarily be manifested by the conceptualization of the problematic range of ideas of unity (Pirogova, 2014). The researcher provides an overview of $\mathrm{H}$. Hesse's prose works, most notably, his philosophical works "Siddhartha", "Steppenwolf", "Demian", "Narcissus and Goldmund". The novelty of the approach refers to the conceptualization of the problematic scope of the ideas of unity, which is extremely important for the aesthetic and philosophical position of the writer and central for the fictional world of most of his novels and stories. The theses performed by Y.Guterman, SchmigelMilha are to be considered as a certain breakthrough in terms of the innovative interpretation of Hesse's works (Guterman, 1999; Schmigel-Milha, 2018). Also noteworthy are the studies conducted by Shelkunova T. (Shelkunova, 2014) and I.L. Mikhailin (Mikhailin, 2016).

Among recent foreign literary studies related to the focused research are the following publications: (Henke, 2018; Darensky, 2018; Drapela, 2016). The research studies (Singh, 2006; 
Jackson, 2010; Shervashidze, 2016; Zlochevskaya, 2012) are regarded as the most conceptually congenial to the current study.

\section{Problem Statement}

In fact, fictional biographies of Josef Knecht still remain underresearched, specifically, in the view of transpersonal psychology, thus, contributing to the novelty and purpose of the article.

\section{Methods and Materials}

The focused research initially refers to K. Jung's understanding of the collective unconscious as a reflection of the universal laws of the human psyche, while S. Grof's identification of a separate kind of human feeling, carried over to other eras, indirectly leads us to the idea of reincarnation (Grof, 1985).

\section{Results}

In a letter to Rudolf Pannwitz (January 1955), Hesse noted: «Die Vorstellung, die den ersten Funken in mir entzündete, war die Reinkarnation als Ausdrucksform für das Stabile im Fliessenden, für die Kontiinuität der Überlieferung und das Geistesleben überhaupt. Es kam mir eines Tages, manche Jahre bevor ich mit dem Versuch einer Manuskript begann, die Viision, eines individuellen, aber überzeitliichen Lebenslaufes: ich dachte mir einen Menschen, der in mehreren Wiedergeburten die grossen Epochen der Menschegeschichte miterlebt. Übriggeblieben ist von dieser ursprünglichen Intention, wie Siie sehen, diie Reihe der knechtschen Lebensläufen, die drei historischen und der kastalischen» (Briefe, 1974: 436). Imagination, flashed through me like a spark, was the idea of reincarnation as a form of expression of the stable in the changing, the succession of traditions and spiritual life in general. It was an image of an individual but timeless life story. I imagined a person who lived in numerous reincarnations in different historical epochs of human history. Several Knecht's biographies were based on this initial concept: three historical and one Castilian (Briefe, 1974: 436). Constructive in this respect is the view of contemporary researchers on distinguishing the image of the traveler as a person striving for novelty and self-transcendence (Ivanova, 2015) as an "aesthetically receptive individual" (Novikova, 2014), as a "way to self" (Miasnikova, 2011). In this regard, the transcendental is specified in terms of the state in which the self recognizes the limits of its existence when it strives for a higher sense that contributes to authentic personal being (Zhukova, 2009).

As V. Frankl's concept suggests: "A human constantly focuses on the exterior, notably, on something or someone: the sense that needs to be realized or another person reached out with love. The more a person transcends themselves, the more they become self-fulfilled" (Frankl, 1985: 2).

The current research regards Josef Knecht's fictional biographies as a kind of transference, as an esoteric technique of moving a person from one part of reality into another, on account of the concentrated energy of his thoughts, intended to implement one of the scenarios considering the concept of multivariant world (Inyushin \& Rozhkova, 2018).

The anonymous narrator in the novel "The Glass Bead Game" defines the form of Knecht's fictional biographies as follows: «Dies war nun freilich nicht etwa ein Glaube im strengen Sinn, noch viel weniger war es seine Lehre, es war eine Übung, ein Spiel der Imagionskräfte, sich das eigene Ich in veränderten Lagen und Umgebungen vorzustellen. Man, übte sich dabei, so wie man es in vielen stilkritischen Seminaren und so oft auch im Glasperlespielen tat, im 
behutsamen Eindringen in vergangene Kulturen, Zeiten und Länder, lernte seine eigene Person als Maske, als vergängliches Kleid einer Entelechie betrachten» (Hesse, 1971: 111).

It is symbolic that the protagonist's biographies conceptually share plot events with an archetypical Castilian plot, and the proper names: Knecht, Famulus, Dasa signify the same notion, that is, a servant; also common is the scenario of the mentor-disciple, the orphanhood of the main character, and the motive of sacrifice.

Contemporary scholars of Hesse's works tend to debate that the biographies represent a kind of a meta-text, is based on the ancient Eastern hypothesis on the transmigration of souls, the strategy that allows for different genre features to function in coherence and consistency incorporating two perspectives - esoteric and exoteric. The esoteric aspect refers to a series of philosophical ideas mediated by the Buddhist schools of thought, exemplified in the text by the motives of "contemplation" and "awakening" (Guterman, 1999).

In his novel, Hesse creates a series of "paradigmatic biographies", enabling him to expand the novel's temporal framework, to "play" with the categories of time and space, incorporating different temporal planes. As a result, Knecht's incarnations are considered in terms of the whole, acquiring super-temporal properties and treated as "turns" of a boundless life process beyond astronomical time. Josef Knecht personates in his fictitious characters, or rather, acting in imaginative life situations.

As Kruglikova V. A. notes, "Knecht's paradox" can only be solved from an arbitrary position. There is no solution to it either, as to any real paradox. But there is another solution corresponding to it in another area" (Kruglikova, 1988: 98-99).

If to dwell in this way, such "another area" for Knecht is his own writing, because that is what he lacks in a "real" Castile, as long as there is no principle of creating individual literary works.

The protagonist of the first biography - The Rainmaker - Knecht is a noble spiritual representative of the primitive communal system. Following his predecessor, he gradually gains knowledge of the world and applies it in favour of the community. In doing so, however, he is engaged with a complete misunderstanding from the aggressive tribal community, which accuses him of failing to prevent a natural disaster (drought). Savagery and delusion were thought to frustrate the protagonist's noble aspirations. However, Knecht's intention endures, he sacrifices himself to preserve the traces of spirituality and bring people out of shock after seeing a cosmic starfall and let his disciple and son (Tura) continue his affair.

The mentor gets the disciple involved in his activities, teaches him artistry, and reveals two important mysteries of the world. The first suggests that there must be some fundamental enabling to perceive the world in its integrity: «Es müsste nun, so schien es Knecht in jenem Augenblick, im riesigen Netz der Zusammenhänge einen Mittelpunkt geben, von dem aus alles gewusst, alles Vergangene und alles Kommende gesehen und abgelesen werden könnte. Dem, der an diesem Mittelpunkt stünde, müsste das Wissen zulaufen, wie dem Tal das Wasser und dem Kohl der Hase, sein Wort müsste scharf und unfehlbar treffen wie der Stein aus der Hand des Scharfschützen, er müsste Kraft des Geistes, alle diese einzelnen wunderbaren Gaben und Fähigkeiten in sich vereinen und spielen lassen: dies wäre der vollkommene, weise, unübertreffliche Mensch» (Hesse, 1971: 492-493).

It is noteworthy that Knecht experienced such a state as rejoicing and sacrament, as the solemnity of consecration: «So etwa empfand er es, und was wir in unser ihm unbekannten, begrifflichen Sprache darüber zu sagen versuchen, kann nichts von deren Schauer und von der Glut seines Erlebnisses mitteilen. (Hesse, 1971: 493).

It should be noted that the daily life of the rainmaker, in view of all the circumstances, is almost no different from that of other tribal members. With his background knowledge and 
ability to manipulate nature, he, however, does not enjoy any privileges (Nemerov, 2016). It is also necessary to consider the fact that the world of sacral meanings did not form into a specific independent semantics: however, it was not something supernatural, but internally natural and combined with the verbal language, moral notions associated with the rank in the tribe, function of the rainmaker (Malchukova \& Malchukova, 2013). Another wisdom that Tura teaches his disciple is that one must always be committed to sacrifice himself for the common good.

The psyche of the primitive human, their mind held only a few basic concepts of causeand-effect relations, principles (matriarchal, patriarchal), that allowed for activating various dialogic mechanisms: personal mental (intellectual), external inter-subjective, as integral mental complex of sacred, magical and real and would account for the origin of moral conceptions (Malchukov \& Malchukova, 2013).

Another biography "The Father Confessor" is a parable about early Christian schemamonks inspired by the idea of salvation and redemption of the world. Leading a saintly, ascetic life, they considered themselves as great sinners rather than ordinary people who fell under influence of the evil and squander. They regarded people as children who were not aware of what they did, whereas, they, schemamonks, possessed true knowledge, were responsible for the salvation of the souls of the faithful.

Joseph Famulus is a representative of a different historical period; he is a person of the cultural vector of historical development. Like Knecht, he is an ascetic, but his way to truth varies: he seeks for peace through confession but lives in social isolation and is concerned exclusively with self-improvement. Joseph Famulus devotes himself to people with his extraordinary kindness, ability to listen to their confession in their sins, alleviating their agonies. Eventually, he becomes disappointed in such a form of devotion, since he recognizes the restrictions of his power and mission and has a feeling of inability to rise high above the vanity. He leaves his hermitage and on the way encounters a more experienced, older confessor, Dion Purgil, who confessed worshippers in a completely different way: he reached them and determined redemption on his own account. In this regard, Knecht is concerned about the insight that occurred to him on finding out that Dion Purgil also had sought a meeting with him since he was experiencing a similar spiritual crisis as well.

The encounter of the two confessors, a kind of the mirror reflection of consciousness, has a positive effect, in which the writer manages to balance the ambivalent moral qualities- Joseph's kindness and gentleness - with Purgil's tendency toward harsher judgment and redemption, reinforcing their faith. Dion Purgil returns to his hermitage and continues his confession: but before doing so, he makes Joseph his servant, disciple, and successor.

Tacit Purgil reveals to Joseph, before his death, another remarkable piece of wisdom about rejuvenation triggered by frustration: «Aber es ist auch überdies jammerschade, wenn ein Mensch in Verzweiflung stirbt. Die Verzweiflung schickt uns Gott nicht, um uns zu töten, er schickt sie uns, um neues Leben in uns zu erwecken. Wenn er uns aber den Tod schick, Josef, wenn er uns von der Erde und vom Leibe losmacht und uns hinüberuft, so ist das eine grosse Freude. Einschlafen dürfen, die man lang getragen hat, das ist eine köstliche, eine wunderbare Sache». (Hesse, 1971: 564).

The life story about Famulus was written according to the stylistic form of the Old Testament legend about the creation of the world, a human strive for world cognition as a manifestation of the primordial sin: «Wenn es ihm vor dem freiwilligen Tode so sehr graute, so spukte in diesem Grauen freilich auch noch ein Rest von vorzeitlichen, vorchristlichen, altheidnischen Wissen, Wissen um den uralten Brauch des Menschenopfers, zu dem der König, der Heilige, der Auserwählte des Stammes ausersehen war, und das er nicht selten mit eigener 
Hand zu vollziehen gehalten war. Nicht nur dass dieser vergöhnte Brauch aus heidnischen Vorzeiten herüberklang, machte ihn so grauenerregend, sondern noch mehr der Gedanke, dass am Ende der vom Erlöser am Kreuz erlittene Tod auch nichts anders war als ein freiwillig vollzogenes Menschenopfer» (Hesse, 1971: 538).

Joseph fulfils the promise given to his mentor Purgil: he digs a grave for him and plants a palm tree on it. According to Hesse, everyone should at least have a disciple and plant a tree.

Spiritual "aggravations", inner crises, epiphanies, and insights not only trigger transpersonal experiences, but they often become such crises that lead to personality change. Spiritual and mental crises, if properly understood and supported, contribute to emotional and psychomatic recovery, self-development, rapid ethical and aesthetic growth of consciousness (Grof \& Grof, 1986).

The third "Indian" biography presents a completely different setting: the prince heirs to the throne, due to intrigues of his stepmother and her son becomes a shepherd, his wife gets seduced by his half-brother, who then succeeds to the throne. Dasa kills the offender, but he has no peace, having to constantly hide from persecution. One day he meets a hermit yogi in the woods, who tells him an amazing parable about the "Maya". Later on, one of his dreams shows Dasa his future: how he succeedes to the throne, the birth of his son, the war, the death of the heir's son, and imprisonment - after which he wakes up, accepts obedience, becomes the yogi's disciple and settles down in the woods forever.

In fact, what Dasi narrated about the Maya refers to a multivalent religious and philosophical concept of illusory true nature of the world and human existence. The yogi hermit on his own managed to break through the superficial sensory perception of the duality of the world and reach the foundation of existence, seeking beyond the basics, for the beginning of the visible world to find the grounds in the essential and unchangeable, to terminate the cycle of birth and death (sansara).

Next encounter of Dashi with the hermit occurs as if in another dimension. By reproducing the process of recollection, Hesse brings his character back to his true spiritual center, describing the whole process as a kind of spiritual awakening.

The speechless yogi reaches the highest level of his self, his enlightened mind is in harmony with the supreme intelligence. The yogi recognizers the irrelevance of verbal communication and his inner voice is heard only at the end of the narrative, upon establishing immediate connection with Dasa as the mentor with the disciple, it occurred to the yogi that Dasa in his previous"births" also strived for "awakening" i.e., spiritual epiphany.

At the end of the "other life" in his doze Dasa coincidentally sees himself with a bottle in a familiar place near a spring. A bottle is a schemamonk's distinctive attribute, a symbol of humbleness and innocence. Filling the bottle with water and presenting it to the mentor with clean hands is a certain form of worship that shows the disciple's readiness to honour the mentor and gain knowledge.

The water jet projects a few moments from his future: in case he tends to be guided by his passions: he will strive for love, glory and power, but actually will be betrayed, experience suffering, moral degradation and failure, feeling all this in himself, Dasa suddenly passes away. Nagornaya N.A. notes that it does not imply his real physical death, rather than the transition to the fictional space beyond the invisible boundary, to the silent world of yoga. Yet, the author's narrative comments die away, as if the spirit of the maya disappears (illusions of life vanish), leaving just devotion behind (Nagornaya, 1998). 


\section{Conclusions}

Thus, the peculiarity of Hesse's individual style of writing, his narration patterns are projected in the writer's individual consciousness in the form of "self" as an archetype of humanism, that unites humanity within time and space of book culture. The sense of particular tension and dynamism in "The Glass Bead Game" is ironically created through the eternal conflict between the self and non-self, that is interpreted as "magical reading of the book of life" and as "recreating the world in itself" (Vasilenko, 2008). Schikander Sinkha, notes that "The Three Biographies of the Master of the Game by Josef Knecht" are unique symbols of the illusory nature of human existence. They are a play of poetic vision, engaging Knecht as well as the readers to play with the historically distant cultures and spiritual worlds, forming an understanding of the relativity of what is treated one's identity (Singh, 2009: 239).

All the three biographies represent a peculiar meta-text, the latter based on the ancient Eastern doctrine of the transmigration of souls: the reader is shown a magical picture of the reincarnation of a culture-bound human soul (Bakalov \& Borodenko, 2012). As is known, in the physical world there is a direct correlation between the phenomena of macrocosm and microcosm, between two models of the Theater of Reality as mirror reflections of each other. As V. Demchog rightly notes, reality does not emerge by itself, it is the result of human intellectual activity. Overall, it seems perfectly clear that the power of a play is underestimated, and the abilities of a personality are also limitless, or rather what the alchemy of play regards as the "possible human", that is "virtual human", who is equally existent and imaginary (Demchog, 2020). Therefore, a human's true mission is not in pursuit of illusory truth, but in liberation from dualistic (bipolar) perception of reality, in achievement of integrity of consciousness, in the comprehension of the current reality through integration of microcosm and macrocosm.

Noteworthy, the fundamental role of David Bohm and Carl Pribram's theory about holomovement suggests that each spatio-temporal part of the world follows the entire order of the universe, specifically, includes the past, present and future. In other terms, similar to a hologram with each segment containing information about the whole fixed object, while each section stores complete information about the structure of the universe as the entire world (Bohm, 1986; Pribram, 1981).

To summarize, the facts illustrated above, accurately represent holotropic consciousness, when an enlightened person transcends the material (physical) self and "connects" to the wholeness of the world, acquiring full identity with it. The analysis of the motive of "awakening" and its role in understanding the main patterns of Knecht's fate allows us to conclude that the protagonist's self-cognition homologates with his perception of the surrounding reality (eyes reflect the world). The center of the personality, the "inner person", is equal to the whole macrocosm and displays Hesse's intention to characterize his protagonist in terms of the absolute transcendental reality, enabling the hero to overcome the crisis of splitting consciousness, breaking the continuity of rational existence and achieving the lost primordial paradise.

\section{References}

1. Bohm, D. (2005). Wholeness and the implicate order. Routledge.

2. Bohm, D.J. (1986) A New Theory of the Relationship of Mind and Matter. Journal of the American Society for Psychical Research, 80(2), 91-123

3. Briefe, A. (1974). Erweiterte Ausgabe. Zusammengestellt von Hermann Hesse und Ninon Hesse. Frankfurt/Main. 
4. Drapela, N. (2016). The price of freedom: identifying the narrator of Hermann Hesse's Das Glasperlenspiel. The German Quarterly, 89(1), 51-66.

5. Frankl, V. E. (1985). Man's search for meaning. Simon and Schuster.

6. Grof, C., \& Grof, S. (1986). Spiritual emergency: The understanding and treatment of transpersonal crises. ReVISION, 8(2), 7-20.

7. Grof, S. (1985). Beyond the brain: Birth, death, and transcendence in psychotherapy. Suny Press.

8. Grof, S. (2016). Realms of the human unconscious: Observations from LSD research. Souvenir Press.

9. Henke, O. (2018). Hermann Hesses Das Glasperlenspiel als Esoterik.

10. Hesse, H., \& Glasperlenspiel, D. (1971). Glasperlenspiels in der Ordensprovinž Kastalien. Nur angefügt sind Knechts. Suhrkamp Verlag

11. Hume, L., \& Drury, N. (2013). The varieties of magical experience: Indigenous, medieval, and modern magic. ABC-CLIO.

12. Jackson, T. (2010). Hermann Hesse as ambivalent modernist.

13. Jung, C. G. (2009). Consciousness and the unconscious. In Consciousness and the Unconscious. Princeton University Press.

14. Pribram, K. H. (2013). Brain and perception: Holonomy and structure in figural processing. Psychology Press.

15. Pribram, K.H. (1981). Non-Locality and Localization: A Review of the Place of the Holographic Hypothesis of Brain Function in Perception and Memory. Preprint for the Tenth JCUS. November.

16. Singh, S. (2006). Hermann Hesse. Reclam.

17. Singh, S. (2009). Hermann Hesse oder Portrait des Schriftstellers als Verwalter seines Nachruhmes (pp. 334-341). Max Niemeyer Verlag.

18. Wilber, K. (1975). Psychologia perennis: The spectrum of consciousness. Journal of Transpersonal Psychology, 7(2). URL: http://citeseerx.ist.psu.edu/viewdoc/download?$d o i=10.1 .1 .1068 .7629 \&$ rep $=$ repl\&type $=p d f$ (Last accessed: 17.03 .2021$)$

19. Wilber, K. (2001). No boundary: Eastern and Western approaches to personal growth. Shambhala Publications.

20. Bakalov, A. S., \& Borodenko, N. V. (2012). Knecht's paradox in Hesse's novel "The Bead Game”. News of Samara Scientific Center of the Russian Academy of Sciences, 14 (2-5), 1232-1235.

21. Borodenko, N. V. (2011). The Confrontation of Two Worlds in H. Hesse's novel "The Bead Game". Proceedings of the Samara Scientific Center of the Russian Academy of Sciences, 13(2-6), $1444-1446$

22. Guterman, Y. O. (1999). Poetics of H. Hesse's novel The Bead Game in the Context of the Philosophy of Buddhism and Taoism: dissertation ... D. in Philology: 10.01.05. Moscow.

23. Darensky, V. Yu. (2018). The prototype of virtual culture in Hesse's novel "The Bead Game”. Science. Art. Culture, (1 (17)).

24. Demchog, V. (2020). The self-releasing game. Moscow: Litres.

25. Zhukova, O. I. (2009). The concept of transcendence and its significance for the analysis of the structure of the self. Vestnik (Herald) of Tomsk State University, (323), 67-72.

26. Zlochevskaya, A. V. (2012). Peculiarities of the Metafictional Chronotope in the Novels of H. Hesse, V. Nabokov, and M. Bulgakov. Vestnik (Herald) of the Moscow University. Series 9. Philology, (3), 25-35. 
27. Ivanova, A.N. (2015). Traveler as a personality with the need for novelty and self-transcendence. Vestnik (Herald) of Tomsk State University, 400, 51-58

28. Inushina, I. A., \& Rozhkova, N. V. (2018). Dialectics and the Symmetry Principle as Methods of Construction of Symbolic Worlds in H. Hesse's Prose. Kant, (2 (27)), 184-193.

29. Malchukov, V. A., \& Malchukova, N. V. (2013). Syncretism of intellect and language in ancient man (by Hesse). Proceedings of the Baikal State University, (4), 131-137.

30. Mikhailin, I. L. (2016). A Prescription for Overcoming Mass Society in Herman Hesse's novel "The Bead Game”. Philological treatises, 2(8), 63-73

31. Myasnikova, L. A. (2011). Journey to yourself (on the novel of Lev Tolstoy "Anna Karenina”). Theory and Practice of Social Development, (8), 15-19.

32. Nagornaya, N. A. (1998). The Myth of Maya in Hesse's novel "The Bead Game”. Culture and text, (3), 81-92.

33. Nemerov, E. N. (2016). Shamanism as a socio-cultural phenomenon. Manuscript, (7-2 (69)), 125-128.

34. Novikova, N. V. (2014). The traveler as an aesthetically perceiving personality (IA Goncharov, MM Prishvin). Scientific Notes of Kazan University. Series Humanities, 156(5), 281-298.

35. Pirogova, N. (2014). The idea of transcendental unity in the works of H. Hesse. Language and Culture., (17, m. 2), 13-18. [in Ukrainian]

36. Seredkina, E. V. (1999). Three models of planetary culture in the context of H. Hesse's novel "The Bead Game". ANTHROPOLOGY. URL: http://anthropology.ru/ru/text/seredkina-ev/tri-modeli-planetarnoy-kultury-v-kontekste-romana-ggesse-igra-v-biser (Last accessed: 17.03.2021)

37. Shelkunova, T. (2014). The code of the game in the novel by H. Hesse "The Bead Game". Scientific Bulletin of the Lesya Ukrainka East European National University. Philological sciences. literary studies, (19), 167-171.

38. Shervashidze, V. V. (2016). Genesis of Hesse's Magic Reality. Vestnik (Herald) of the Peoples' Friendship University of Russia. Series: Literary Studies, Journalism, (2), 85-92

39. Schligel-Milch, M. A. (2018). Hermeneutics of mythological structures in German modernist literature (on the material of the works of Novalis and H. Hesse: abstract of the thesis for the degree of Candidate of Philological Sciences: 10.02.04; supervisor V. B. Merkuryeva; Russian State Pedagogical University. St. Petersburg. 